\title{
Teknologistøttet ferdighetstrening for sykepleierstudenter i desentralisert utdanning
}

Catrine Buck Jensen, Ole Johan Olsen og Bente Norbye

Våren 2017 ble et pilotprosjekt gjennomført ved den desentraliserte sykepleierutdanningen ved UiT Norges arktiske universitet, med deltakelse av sykepleierstudenter. Et tett samarbeid med University of Saskatchewan i Canada førte til at vår prosjektgruppe fikk låne en mobil telemedisinsk enhet som ble utprøvd i undervisning og øving på praktiske ferdigheter for studenter i Nord-Troms. Studentene måtte forholde seg til teknologi, veiledere og hverandre på en annen måte enn de tidligere hadde gjort, noe de fleste av dem opplevde som positivt. Vi ønsker gjennom dette kapittelet å vise hvordan undervisningen ble gjennomført, og gjennom analyse av studentenes og lærernes refleksjonslogger diskutere studentenes og lærernes erfaringer med bruk av teknologistøttet ferdighetstrening.

\section{Innledning}

Gjennom bachelorutdanningen i sykepleie trener studentene på forskjellige ferdigheter relatert til klinisk praksis. Det første studieåret legger vekt på grunnleggende ferdigheter, som f.eks. hvordan bistå en pasient med personlig hygiene, hvordan re opp en seng, observasjon av normale og unormale tilstander hos pasienten. I utdanningens andre og tredje år er ferdighetene i større grad relatert til læringsutbyttet for klinisk praksis, f.eks. hvordan opprette en intravenøs tilgang, hvordan gi 
intravenøs behandling eller hvordan gjøre i stand ulike former for legemidler. Ferdighetstrening gjennomføres tradisjonelt i ferdighetsrom som ligner mye på et klinisk miljø, for eksempel et pasientrom i sykehus. Bruk av simulering for trening av prosedyrer er vanlig i sykepleierutdanningene verden over, der studentene trener ferdigheter ved hjelp av simuleringsdokker som f.eks. sim-man (Dean, Williams \& Balnaves, 2015; Munshi, Lababidi \& Alyousef, 2015; Yuan, Williams \& Fang, 2012). Det er imidlertid mindre bruk av andre former for simuleringstrening som utfordrer avstand i desentraliserte studier, der studenter tar i bruk velferdsteknologi for å minske avstand mellom lærested og der studentene er, men noen nye former for læring og utstyr er utprøvd (Butler, Bullin, Bally, Tomtene \& Neuls, 2016).

Sykepleieutøvelse består av mange praktiske ferdigheter. Disse ferdighetene knyttes ofte til handlinger og prosedyrer som ivaretar pasientens fysiske og psykiske velvære. De bidrar til pasientsikkerhet og utgjør en avgjørende del av sykepleiepraksisen (Bjørk, 2003). Patricia Benner, Molly Sutphen, Victoria Leonard og Lisa Day (2010, s. 1) hevder at «nye sykepleiere trenger å bli forberedt på å praktisere sikkert, nøyaktig og omsorgsfullt i varierte situasjoner, hvor kunnskap og innovasjon øker i et forbløffende tempo».

\section{Kontekst for studien}

Northern Nursing Education Network er et internationalt nettverk som støtter utdanninger av sykepleiere i distrikt over tre kontinent og gjennom 14 sykepleierutdanninger. Nettverket danner basis for et internasjonalt samarbeid, der vi sammen utforsker digitale muligheter for å imøtekomme studentenes behov for undervisning også der det er stor avstand mellom campus, studenter og lærested. Våren 2017 gjennomførte tre lærere ved sykepleierutdanningen ved UiT Norges arktiske universitet et pilotprosjekt med en innovativ tilnærming til ferdighetstrening for sykepleierstudenter $\mathrm{i}$ andre semester. Studentene var tatt opp på den fireårige desentraliserte sykepleierutdanningen (DSU) ved UiT Norges arktiske universitet. Læringsaktivitetene ved den desentraliserte sykepleierutdanningen er til vanlig en kombinasjon av undervisning med fysisk tilstedeværelse av lærer og/eller studenter, og nettbaserte aktiviteter. Dette kan defineres som «blended learning» (Daniel, 2017; Margaryan, Collis \& Cooke, 2004). Sykepleierutdanningen ved University of Saskatchewan, som en del av det internasjonale nettverket, lånte 
prosjektet en bærbar telemedisinsk enhet av typen InTouch RP-Xpress. Denne brukes tradisjonelt til fjernkonsultasjoner mellom spesialisttjenester og klinikker for pasienter med bosted i distriktet. I kliniske sammenhenger har denne enheten vært brukt for å vurdere nødvendigheten av å legge inn syke barn på sentrale sykehus, eller om behandlingen av barnet kan skje ved lokalsykehuset (Holt, Hansen, McKinney \& Mendez, 2018).

På sykehusavdelinger brukes en lignende enhet i full størrelse som kan styres og beveges i rommet, ${ }^{1}$ denne viser levende bilde av spesialisten på toppen av enheten med lyd og bilde, derav navnet «robotteknologi».

\section{InTouch Health}

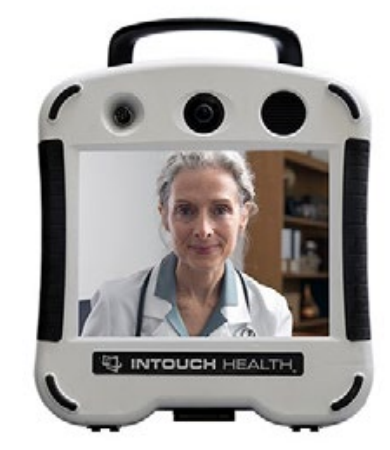

Den telemedisinske enheten fra produsenten InTouch Health

\section{Utprøving av telemedisinsk utstyr}

Sykepleierutdanningen ved University of Saskatchewan har etablert et mobilt utstyr for å tilby fjernveiledning i ferdighetstrening for studentene i nordlige provinser i Canada (Butler et al., 2016), såkalt remote presence (ekstern tilstedeværelse). ${ }^{2}$ Den mobile enheten er på størrelse med en middels stor PC-skjerm med håndtak og kan flyttes rundt ved behov. Eksempelvis kan den brukes ved fjernkonsultasjoner i hjemmebesøk hos pasienter for å konsultere en spesialist. ${ }^{3}$ Operativsystemet er Windows XP8. Selve oppkoblingen skjer via internett ved hjelp av egen programvare for å ivareta pasientsikkerheten. Kommunikasjon skjer via lyd-bilde og gjennom tilkoblet utstyr. I motsetning til ordinære datamaskiner og lyd-bilde-applikasjoner (eksempelvis Zoom, Microsoft Teams eller Skype) kan man i tillegg koble medisinsk-teknisk utstyr til enheten, eksempelvis stetoskop, otoskop, oftalmoskop eller munnhule-kamera (Butler et al., 2016). I prosjektet brukte vi et

\footnotetext{
For bilde; se https://journals.sagepub.com/doi/full/10.1177/1177180118806430

2 I den canadiske litteraturen knyttet til denne teknologien brukes begrepet Remote Presence (RP) robotics (Butler et al., 2016), men vi har bevisst valgt å utelate robotbegrepet i denne teksten, da det kan være litt utydelig hva det innebærer. I dagligtalen med studentene har imidlertid begrepet vært i bruk, og det ser man også ved at studentene har tatt det i bruk i sine refleksjoner og uttalelser.

3 Et EU-prosjekt om Telemedical Robotics har utforsket et tilsvarende utstyr, kalt The Giraff Telepresence.
} 
spesialtilpasset elektronisk stetoskop til ferdighetstreningen for blodtrykksmåling og respirasjon. Studentene kunne dermed lytte til hjertelyder, lungelyder og måle blodtrykk på hverandre samtidig som fjernveilederen, lokalisert 26 mil unna, hørte den samme lungelyden, og blodtrykksmålinger som studentene gjorde via stetoskopet. Studentene ble da veiledet ved gjenkjenning av lydene samtidig med læreren. Skjermoppløsningen var tilfredsstillende og ga et tydelig bilde av fjernveilederen som studentene kommuniserte med. Fjernveilederen viste bilder og veiledningsmateriale til studenter i sanntid.

Hensikten med pilotprosjektet var først og fremst å utforske om det var mulig å gjennomføre ferdighetstrening ved bruk av teknologien som denne bærbare enheten representerte. Samtidig var vi bevisst på at de som fremtidige sykepleierne i distriktene, og gjennom selv å bruke en slik type teknologi i utdanningen, så potensialet for dette i senere pasientarbeid (Holt, Hansen, et al., 2018; Holt, Sari, et al., 2018).

I dette kapittelet vil vi utforske følgende spørsmål: Hvordan blir sykepleierstudenters læring påvirket gjennom bruk av telemedisinsk teknologi?

\section{En casestudie: ferdighetstrening med teleteknologi}

I pilotprosjektet ble fire tema valgt ut som passende for utprøving av ferdighetstrening med veiledning mediert gjennom den bærbare enheten. Hvert tema hadde ulike grunnleggende ferdigheter som studentene skulle lære. Temaene var 1) inspeksjon av munnhule, 2) observasjoner knyttet til sirkulasjon, 3) observasjoner knyttet til respirasjon og 4) sårstell og hygiene. Eksempler på ferdigheter det ble øvd på, var blodtrykksmåling, palpasjon av puls, auskultasjon av lungelyder og aseptisk teknikk og sårstell.

Studentene ble delt inn i to grupper à seks til åtte studenter. Av hensyn til det fysiske rommet ferdighetstreningen skulle foregå i, og for å unngå for store grupper av studenter ble hver temaøkt organisert med to parallelle runder. I tillegg hadde vi kun tilgang til én pasientseng som kunne brukes i ferdighetstreningen. De fysiske forholdene medførte at den ene gruppen utførte ferdighetstrening sammen med fjernveilederen, samtidig som den andre gruppen var sammen med den lokale veilederen for teoretisk introdukjon til tematikkene. Innholdet i ferdighetstreningen var både praktisk opplæring samt diskusjon og refleksjon rundt tilhørende teori, retningslinjer 
og prosedyrer. Studentene simulerte pasienter og brukte dermed hverandre for å øve på de ulike ferdighetene. Veilederteamet besto av en lokal veileder på studiestedet og en fjernveileder lokalisert på hovedcampus. Disse planla og gjennomførte ferdighetstreningene. Etter hver undervisningsøkt skrev studentene og lærerne refleksjonslogger som senere ble en del av datamaterialet.

\section{Metodisk tilnærming}

Datamaterialet ble samlet inn mellom januar og mars 2017. Rekruttering av informanter til studien skjedde ved et beleilighetsutvalg, da vi ønsket studenter fra et desentralisert studiesenter i Troms fylke, der studentene gjennomfører størstedelen av sykepleierutdanningen (Skaalvik \& Norbye, 2016). For å undersøke bruken av teknologistøttet ferdighetstrening i sykepleierutdanning i distriktene har vi brukt en kvalitativ casestudiedesign med flere typer data (Baxter \& Jack, 2008). Dette fordi vi ønsket å utforske begge sider av undervisningen - både studentenes og lærernes erfaringer med det nye verktøyet som muliggjorde ferdighetstrening på distanse, og hvordan konteksten innvirket på læring.

\section{Refleksjonslogger}

Etter hver temaøkt skrev studentene individuelle refleksjonslogger der de reflekterte over egen læringsprosess og den praktiske implementeringen som kunne påvirke læringen, hhv. refleksjon over egen læring, organisatoriske aspekter og teknologiske aspekter. Fjernveilederen skrev logg etter hver temaøkt mens den lokale veilederen skrev en retrospektiv logg da pilotutprøvingen var gjennomført. Til sammen skrev studentene 39 refleksjonslogger, fjernveilederen skrev fem og den lokale veilederen skrev én. Alt ble skrevet på norsk. Refleksjonsloggene ble analysert slik de forelå da de ble skrevet. 


\section{Videomateriale}

Det ble gjort videoopptak av temaøkt 2 og 3. Materialet inneholdt ni videoer med en varighet fra syv til 20 minutter. To av videoene ble ved en feil tatt opp uten lyd, og dataene kunne derfor ikke analyseres, da det ikke var mulig å trekke meningen ut av samtalen. Disse ble ekskludert fra materialet. Videoopptakene ble gjennomført fra et hjørne i rommet hvor ferdighetstreningen fant sted. Videoene viser både studentene som øver på ulike praktiske ferdigheter, og den bærbare enheten med fjernveilederen synlig. Filmene ble tatt opp uten å zoome inn eller ut. Studentene var klar over at de ble filmet.

\section{Etiske betraktninger om forskningsprosessen og forskerrollen}

Studien er godkjent av Norsk senter for forskningsdata (NSD, ref.nr. 51426) og av Institutt for helse- og omsorgsfag, UiT Norges arktiske universitet, hvor studien fant sted. I søknad til NSD var teknologien beskrevet, noe den også ble for deltakerne i informasjonsskriv. Alle deltakerne har gitt skriftlig samtykke og var informert om de ulike metodene for datasamling, både refleksjonslogger og videoopptak.

Forskernes posisjoner i studien har vært viktige å ha med i forskningsprosessen. Av forfatterne var Catrine Buck Jensen (CBJ) både underviser og deltaker i analysen og er førsteforfatter av artikkelen, og har innenfraperspektivet som gir innsikt, men liten distanse til materialet og analysen (Elden \& Levin, 1991). Ole Johan Olsen (OJO) var lokal veileder og har bidratt til å underbygge funnene underveis, også med et innenfraperspektiv. Bente Norbye (BN) var prosjektleder, men ikke til stede under undervisningen, og har slik hatt en utenforposisjon knyttet til analysen av materialet (Elden \& Levin, 1991). Bias har vært diskutert ved flere anledninger, og vi har forsøkt å være tro mot datamaterialet og analysen i prosessen (Creswell \& Poth, 2018).

Analyse av datamaterialet

Analysen av det skrevne materialet, refleksjonsloggene, var gjennomført som en refleksiv tematisk analyse (Braun \& Clarke, 2006, 2020). I refleksiv 
tematisk analyse er forskerens subjektivitet en analytisk ressurs som gjennom arbeid med teori, data og tolkning har betydning for analysen (Braun \& Clarke, 2020). I denne analysetilnærmingen gjør man seg kjent med datamaterialet og koder deler av datamaterialet som oppleves relevant for å besvare forskningsspørsmålet. En kode er noe som representerer et aspekt ved forskningsspørsmålet (Braun \& Clarke, 2013), i vårt tilfelle kunne det f.eks. være «opplever læring» eller «konstruktiv tilbakemelding». Kodingen i vårt tilfelle var induktiv, det vil si at den var utledet fra datamaterialet og våre tidligere erfaringer, ikke fra et gitt teoretisk perspektiv (Braun \& Clarke, 2020). Videre ser forskerne på kodene under ett og kategoriserer dem innenfor ulike tema og undertema. Tittel på tema blir bearbeidet og dekkende for innholdet (Braun \& Clarke, 2013). Begge forskere (CBJ og $\mathrm{BN}$ ) som deltok i analysearbeidet, har sykepleierbakgrunn og hadde fra tidligere flere positive erfaringer med bruk av teknologi i undervisning, dette må tas i betraktning når det gjelder analysen.

$\mathrm{CBJ}$ og BN gjennomførte de første fasene av analysen sammen. For å bli kjent med datamaterialet gjorde vi først en naiv lesning etterfulgt av en gjennomlesning der vi individuelt skrev initiale koder gjennom hele lesningen. Videre sammenlignet vi de initiale kodene og fortsatte analysen ved å gå tilbake til temaene der noen overlappet, og noen var under en ny overskrift. Denne fasen resulterte i fem hovedtemaer: 1) Teknologiske aspekter 2), Læringsutbytte, 3) Organisatoriske aspekter, 4) Studentaktivitet og 5) Veiledning.

Deretter så vi gjennom videomaterialet for å identifisere nyanser som støttet analysen av refleksjonsloggene, eller som bidro til andre tematikker som vi ikke fikk med i det skriftlige materialet. Vi valgte å gjøre en forenklet analyse av videomaterialet, uten transkripsjon, men med utvalgte sekvenser som grunnlag for diskusjon og analyse (Bezemer \& Mavers, 2011). A transkribere videoopptak er et omfattende arbeid og kan gjøre at mye av merverdien ved et videoopptak forsvinner (Garcez, Duarte $\&$ Eisenberg, 2011). Før analyseprosessen startet, utarbeidet vi et analyseskjema hvor følgende punkter var inkludert: tidspunkt, beskrivelse av hva som skjer/sies, egne kommentarer og foreløpige analysekategorier. CBJ så først gjennom filmene i sin helhet og så deretter gjennom og noterte situasjoner som var av betydning. Kategoriene fra analysen av refleksjonsloggene ble brukt som grunnlag for analysen av videoopptakene, også nye aspekter ble identifisert gjennom hele første trinn av analysen. Videoopptakene, analyseskjemaene med notater og et sammendrag av første trinn ble deretter sendt til BN, som så gjennom de 
samme sekvensene. Dette ble etterfulgt av en felles diskusjon mellom CBJ og $\mathrm{BN}$ om de foreløpige funnene.

Den samlede analysen av de skriftlige refleksjonsloggene og videomaterialet førte til tre hovedtemaer som belyser hvordan den telemedisinske enheten i ferdighetstrening påvirker 1) studentenes læring og læringsutbytte, 2) studentenes rolle og aktiviteter og 3) veilederens rolle og veiledningsaktivitet.

\section{Funn}

I det følgende presenterer vi de tre hovedtemaene som ble resultatet av den samlede analysen av refleksjonslogger og videoopptak.

\section{Egenrapportert læring og læringsutbytte av ferdighetstreningen}

Funnene fra studentenes refleksjonslogger viser generelt positive holdninger til denne læringsaktiviteten og til egenrapportert læringsutbytte.

I den første refleksjonsloggen uttrykte tre av fjorten studenter at de var usikre på om læring ved hjelp av en telemedisinsk enhet var en god metode eller ikke. De resterende var utelukkende positive til å prøve det ut. Etter alle temaøkter rapporterte studentene at de opplevde å ha lært prosedyren selv om de ikke alltid utdypet sine refleksjoner rundt dette. Læringsutbytte ble også eksplisitt rapportert av halvparten av studentene etter den første økta, selv om studentene da ikke var fortrolige med teknologien. En student skrev i sin refleksjonslogg etter første temaøkt: «Litt tidlig å si noe om læringsutbytte på nåværende tidspunkt, men jeg tror dette kan være en fin måte å lære på.»

Ferdighetstrening ved hjelp av den telemedisinske teknologien ble av flere studenter $\mathrm{i}$ vår studie uttrykt som likeverdig med annen (tradisjonell) ferdighetstrening. Flere av studentene hadde yrkesfaglig bakgrunn og hadde opplevd dette i tidligere utdanning. Studenter rapporterte at de fikk erfaring ved f.eks. å simulere en pasient eller å måtte prøve ut sine ferdigheter på medstudenter.

Videomaterialet støttet dette og viste aktive studenter som var fokusert på ferdigheten de trente på. Studentene var konsentrerte rundt arbeidet med 
prosedyren, og det var veldig lite utenomsnakk blant studentene i forbindelse med temaøktene. Samtalene mellom studentene viste samarbeid og faglige diskusjoner.

Temaøktenes organisering ble kommentert av studentene og kan sees i sammenheng med læring og læringsutbytte. Studentene rapporterte at gruppestørrelsen var viktig, både når det gjaldt tilgang til veileder og lydnivået $\mathrm{i}$ rommet. Studentene måtte vente på tur og måtte selv henvende seg til fjernveilederen og i liten grad omvendt. Dette kan ha påvirket opplevelsen av veiledning. Om refleksjoner knyttet til den praktiske gjennomføringen skrev en av studentene: «Kanskje ha mindre grupper slik at vi får tettere oppfølging. Blir vanskelig å spørre om råd eller veiledning når roboten bare står på bordet og mange medstudenter som går rundt i rommet og lager støy».

Den lokale veilederen og fjernveilederen gjorde tilpasninger etter hver temaøkt. Flere studenter kommenterte dette, og noen av dem evaluerte de påfølgende øktene som bedre organisert. En student rapporterte etter den andre temaøkta: «Teknologien var på vår side $\mathrm{i}$ dag, så organiseringen og undervisningen var bra.»

I analysen av videomaterialet ble vi oppmerksomme på at enkelte studenter utførte prosedyrene på feil måte, f.eks. da en student brukte tommelen da hun kjente på pulsen på håndleddet til en medstudent. Dette ble ikke fanget opp av fjernveilederen fra perspektivet vedkommende hadde fra den telemedisinske enheten, og studenten ble derfor hverken veiledet eller korrigert på dette.

Da studentene skulle forberedes teoretisk, brukte fjernveilederen illustrasjoner og fotografier for å forklare oppgaven. Dette kan ha hatt positiv innvirkning på studenter som lærer bedre av visuelle metoder. En student oppsummerte etter fjerde temaøkt at det var «synd at det var siste undervisning med roboten. Jeg har hatt stort utbytte av litt variert undervisning.»

\section{Studentenes roller og aktiviteter under ferdighetstrening}

Både refleksjonsloggene og videomaterialet viser at ferdighetstrening med denne teknologien fokuserer studentaktiviteten tydelig på det aktuelle temaet. Videoene viser at studentene var delvis aktive under gjennomgang av teori, mens de var svært aktive og fokuserte under treningen, som allerede nevnt. En student skrev i refleksjonsloggen: «Lærer bra med å få teori først og få se på prosedyren for så å utføre den selv med veiledning.» 
Flere av studentene hadde arbeidserfaring fra helsevesenet. Dermed ble noe av ferdighetstreningen teoretisk og praktisk repetisjon heller enn ny kunnskap. I noen tilfeller utnyttet fjernveilederen forkunnskapene deres, noe studentene oppfattet som positivt. En av dem sa: «[...] det var en lærerik dag, selv om det for min del ble mye repetisjon. Men siden man har gjort dette før fikk man ta del i å veilede medstudenter i gruppa.»

Fjernveilederen bemerket i sin logg at selv om internettilkoblingen ble brutt, fortsatte studentene ferdighetstreningen. Også studentene kommenterte dette: «Det var nettverksbrudd i dag, men det påvirket ikke nevneverdig. Dette siden vi var satt godt i gang.» Analysen av videomaterialet viser også at studentene generelt jobbet selvstendig med oppgavene og fortsatte selv om robotforbindelsen falt ut.

\section{Veilederens rolle og veiledningsaktivitet i ferdighetstreningen}

De fleste studentene uttalte seg positivt om sine erfaringer med fjernveiledning, og i noen tilfeller mente de at det var like bra som å ha en lokal veileder. Andre studenter savnet imidlertid en veileder som var fysisk til stede i ferdighetstreningen og kunne vise prosedyren man skulle øve på «hands-on». En av studentene knyttet dette opp mot tilbakemeldinger da vedkommende skrev: «Savnet å ha noen som er fysisk tilstede som instruerer, men læreren var veldig flink til å gi tilbakemeldinger.»

Tilbakemeldinger var et viktig aspekt studentene skrev om i refleksjonsloggene. De fleste kommentarer om tilbakemeldinger fra fjernveilederen var positive med hensyn til hvordan studentene opplevde veiledningen: «Fint med tilbakemeldinger underveis i ferdighetstreningen. Fint at veilederen kan vise bilder og forklare. Dette gjør det enklere å vite hva vi skal gjøre.»

På ett punkt i løpet av de fire temaøktene så det ut til at skillet mellom fjernveilederen og selve enheten ble visket ut. Dette ble bemerket i forskjellige refleksjonslogger, og studentene skiller ikke mellom fjernveileder og robot i tekstene sine. En student skrev: «Roboten var klar og tydelig.» En annen student skrev: «Enkelt å føre samtale med roboten.» Om dette var for enkelhetens skyld, er vanskelig å analysere, men ved et tilfeldig møte mellom fjernveilederen og studentene som deltok i temaøktene noen måneder etter 
pilotprosjektet, utbrøt en av studentene «Der er jo roboten!» da den møtte fjernveilederen i korridoren.

Samlet sett tolker vi at studentene uttrykte at de opplevde å bli «sett og hørt» av fjernveilederen til tross for at vedkommende ikke var fysisk til stede. En av studentene hadde tilsynelatende en meget positiv opplevelse med denne læringsaktiviteten: «Det å kunne kommunisere med en lærer som er en helt annen plass, er helt fantastisk.»

\section{Teknologi i læring av praktiske ferdigheter og veiledning av disse}

\section{Hvordan har telemedisinsk teknologi påvirket studentenes læring av praktiske ferdigheter?}

Å lære praktiske ferdigheter i sykepleie har blitt omtalt og utforsket av flere. Benner (1984) viste hvordan Dreyfus og Dreyfus sin modell for tilegnelse av praktiske ferdigheter også har relevans for sykepleie. Hun argumenterer for hvordan man går stegvis fra novise til ekspert i læring av praktiske sykepleieferdigheter, hun beskriver fem steg: Fra «novise» til «avansert nybegynner» og videre til «kompetent utøver», som utvikler seg til en «kyndig utøver», og som gjennom lang praksis til slutt kan ansees for å være «ekspert» (Benner, 1984). For sykepleierstudenter i sitt første studieår tar vi utgangspunkt $\mathrm{i}$ at studentene trenger grundig innføring i gjennomføring av prosedyrene, som nybegynnere. Som noviser handler mye om å følge gitte prosedyrer og regler for fremgangsmåte, og som nybegynner prøver en å ikke avvike fra prosedyren. Når studenten utvikler seg til avansert nybegynner og får erfaring med ulike situasjoner, kan vedkommende begynne å se andre aspekter og i så måte forstå prosedyren man skal utføre, utover de gitte reglene. Dette kan for eksempel innebære at en sykepleier med lang erfaring ikke trenger en oppskrift på hvordan en prosedyre skal gjennomføres, den kjenner innholdet og utfører prosedyren i henhold til gjeldende prinsipper og med tilpasninger knyttet til pasientens behov. Noen av studentene var ansatt i pleie- og omsorgstjenesten og hadde erfaring med gjennomføring av prosedyren og kunne bidra til praktiske løsninger om hvordan stetoskopet kunne holdes for 
å unngå sjenerende støy. Disse kunne regnes som avansert nybegynner, men samtidig være styrt av regler og rekkefølger i aktiviteten de bedrev.

Vi har støttet oss til Ida Torunn Bjørk sin definisjon av hva en praktisk ferdighet er, altså: «Det du fysisk 'gjør' med og for pasienten, inkludert nødvendige forberedelser og etterarbeid» (Bjørk \& Bjerknes, 2003, s. 88). Bjørk har også utviklet en egen modell for læring av praktiske ferdigheter i sykepleie som er mye anvendt i norske sykepleierutdanninger så vel som internasjonalt. Denne modellen gir et helhetlig syn på hva en praktisk ferdighet består av. Den inkluderer og integrerer det «som til sammen omfatter det sentrale i alle praktiske sykepleiehandlinger. Kategoriene er: Substans og sekvens, nøyaktighet, flyt, integrasjon og omsorgsfull væremåte» (Sommer et al., 2011). Disse kategoriene er til stede i all praktisk ferdighetsutøvelse. Hvordan kategoriene tilpasses det kliniske miljøet (med forskjellige pasienter i forskjellige situasjoner), gir en indikasjon på kvaliteten på handlingen som finner sted. Pilene fra den ytre sirkelen, «omsorgsfull væremåte», jf. figur 1 , viser at denne komponenten skal inkluderes i alle kategoriene, da den utgjør selve grunnlaget for sykepleie (Sommer et al., 2011). Dette handler om at uansett prosedyre sykepleieren gjennomfører, skal vedkommende opptre omsorgsfullt gjennom eksempelvis varsomt håndlag, lyttende holdning eller gjennom samtale underveis.

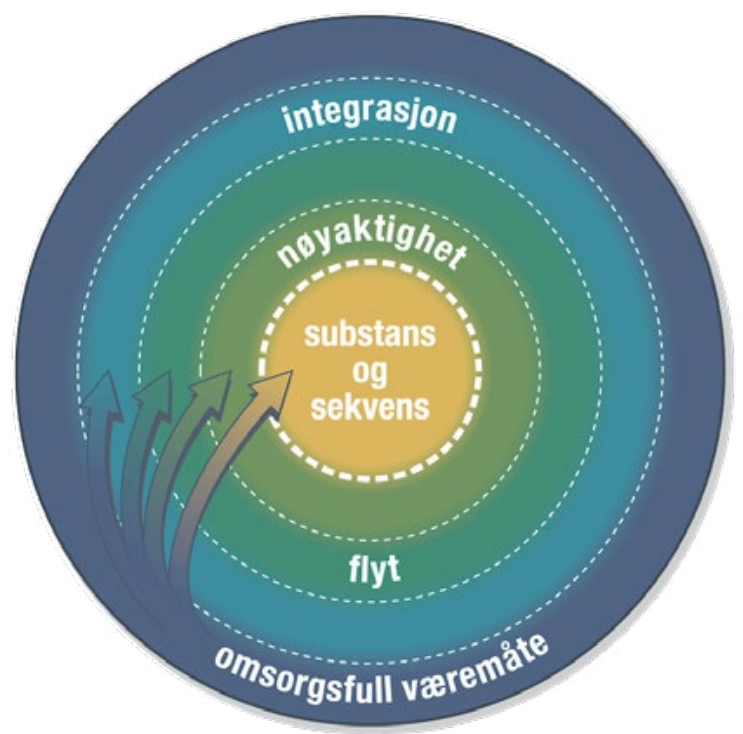

Figur 1: Modellen for praktisk ferdighetsutøvelse (Bjørk, 1999). www.rins.dk 
I temaøktene la vi til grunn ferdighetsnivået til studentene (novisenivået), og fokus var rettet mot «substans og sekvens», jf. Bjørk (1999). Med substans og sekvens menes selve innholdet i handlingen eller prosedyren som skal gjennomføres, og hvilken rekkefølge dette skal gjøres i (Bjørk \& Bjerknes, 2003). Eksempelvis da studentene skulle øve seg på å måle blodtrykk, var det først en gjennomgang av hvorfor man måler blodtrykk, hva blodtrykket er et uttrykk for, hva slags utstyr man bruker, hvordan lyden man hører i stetoskopet skal tolkes (innholdet), for deretter å gjennomgå rekkefølgen (sekvensen): Ta på mansjetten ca. $3 \mathrm{~cm}$ over albueleddet, finn pulsen og plasser stetoskopet, pump opp mansjetten osv. (VAR Healthcare, 2018). Det er interessant å stille spørsmål om hvordan det å lære denne delen av prosedyren ved hjelp av fjernveileder og den telemedisinske enheten påvirker læringen. Studentene selv rapporterte at de hadde lært prosedyren som i forventet. Fjernveilederen gjorde i stor grad det samme som vedkommende ville gjort i tradisjonell ferdighetstrening; lyttet sammen med studentene og gjorde dem oppmerksomme på lyden de skulle lytte etter. Noen studenter savnet den fysiske tilstedeværelsen til veileder. Da de øvde på prosedyren kom noen mer erfarne studenter veilederen til unnsetning. De demonstrerte med håndlag og viste medstudentene hvordan dette skulle utføres. Slik "peer learning» (Boud, Cohen \& Sampson, 2014) gjorde at studentene sa at de opplevde at de både fikk repetert kjent fagstoff, men også at de fikk bruke sine erfaringer og ferdigheter $\mathrm{i}$ å veilede andre studenter. På den ene siden kan dette gjøre studentene mer ansvarlige og skape læring og mestring utover det gitte læringsutbyttet om å lære blodtrykksmåling. På den andre siden kan dette medføre at studentene som måtte veilede medstudenter, ikke fikk arbeidet med sin nøyaktighet og flyt i prosedyren, og på den måten ikke fikk videreutviklet egne ferdigheter i prosedyren. Dette kunne lettere ha vært fanget opp om veileder hadde vært fysisk til stede i rommet.

Læringsaktivitetene kan defineres som «blended learning» (Daniel, 2017; Margaryan et al., 2004). Dette innebærer undervisning som til sammen har både fysisk tilstedeværelse av lærer og/eller studenter, har nettbaserte aktiviteter og tilbyr fleksibilitet (Daniel, 2017). Mange av studentene mente at ferdighetstrening på denne måten var en god måte å lære på, og at teknologien bidro til variasjon i læringsaktiviteter. Til tross for at de fleste studentene uttrykte positive refleksjoner rundt den teknologiske løsningen, kan man i noen grad tolke at den skapte en barriere for kommunikasjonen. Uten at man kan konkludere ut fra vårt materiale, så kan man stille spørsmål ved om den ytterste sirkelen i 
Bjørk (1999) sin modell, omsorgsfull væremåte, var utgangspunktet for veiledningen. Opplevde alle studentene at deres behov for å bli veiledet ble møtt? For eksempel når student og fjernveileder skulle gjennomføre blodtrykksmåling ved hjelp av roboten, ble fokuset raskt rettet mot selve prosedyren og i mindre grad mot personen som prosedyren skulle utføres på. Dette kunne kanskje vært ivaretatt bedre gjennom planleggingen mellom fjernveileder og den lokale veilederen.

Som noen studenter skrev i sine refleksjonslogger, var fjernveilederen og den lokale veilederen lite samkjørte og til dels ukoordinerte den første økta, noe som førte til at innholdet ble gjentatt flere ganger. Utviklingen av tett samarbeid mellom veilederne ser ut til å være vesentlig for studentenes læringsaktiviteter og for å sørge for at innholdet ikke overlappet for mye. I løpet av pilotprosjektet var det en progresjon i temaøktene, noe som kan tilskrives både tilbakemeldingene fra studentene, det kontinuerlige samarbeidet og direkte tilpasninger før og etter hver temaøkt. Å ha tid til å diskutere tilpasninger på forskjellige måter som har innvirkning på temaøktene, skaper en felles forståelse blant veilederne om formålet med ferdighetstreningen og det forventede resultatet. Den kontinuerlige diskusjonen og forhandlingen mellom veiledere kan forstås som en tidlig fase i å skape et praksisfellesskap med forståelse for hva som er grunnlaget for hva man gjør, og hva man anser som god praksis når ferdighetstrening gjøres på denne måten (Lave \& Wenger, 2003). Forhandlinger mellom veilederne om ulike aspekter ved innhold og organisering $\mathrm{i}$ temaøktene kan dermed ha innvirkning på studentenes læringsprosesser.

\section{Hvordan har teknologien påvirket veiledningen?}

Veiledning defineres og tolkes på forskjellige måter av ulike forskere og forfattere innen feltet (Bjørndal, 2011; Lauvås \& Handal, 2014; Tveiten, 2013). Sidsel Tveiten (2013) definerer veiledning som «en formell, relasjonell og pedagogisk istandsettingsprosess som har til hensikt at fokuspersonens mestringskompetanse styrkes gjennom en dialog basert på kunnskap og humanistiske verdier» (s. 21). Veiledning er en viktig pedagogisk aktivitet der konteksten og formålet er viktigere enn hvilket begrep man velger å anvende (Bjørndal, 2011; Lauvås \& Handal, 2014). Når det gjelder veiledning i praktisk ferdighetstrening, kan begrepet "yrkesfaglig veiledning» være aktuelt å bruke (Lauvås \& Handal, 2014), da innføring i og øving på 
praktiske ferdigheter er en del av utdanning til profesjonen sykepleier og utøvelsen av dette. Grunnlaget for veiledning av studentene i vårt pilotprosjekt var både de praktiske ferdighetene som man forventet at studentene skulle tilegne seg, i tillegg til refleksjoner om hvordan disse ferdighetene kunne utføres i en klinisk setting med pasienter. I denne konteksten blir både teoretisk kunnskap og humanistiske verdier som for eksempel selvbestemmelse og verdighet, også grunnlag for veiledning og refleksjon.

Studentene rapporterte generell tilfredshet med fjernveiledningen. Kanskje noe overraskende var studentenes oppfatning av veiledning med støtte av teknologi stort sett positiv. Som nevnt savnet et par studenter «hands-on»-veiledning, men de resterende uttrykte tilfredshet med måten de ble veiledet på. Vi vet imidlertid lite om studentenes tidligere erfaring med veiledning, og kanskje ville kritiske innvendinger økt med mer erfaring som sykepleierstudenter og med å delta i faglig veiledning.

Tilbakemeldinger fra veilederen ble også generelt opplevd som positivt.

John Hattie og Helen Timperley (2007) har konseptualisert begrepet tilbakemelding og definerer det slik:

Feedback is information provided by an agent (e.g., teacher, peer, book, parent, experience) regarding aspects of one's performance or understanding. It occurs typically after instruction that seeks to provide knowledge and skills or to develop particular attitudes (Hattie $\&$ Timperley, 2007, s. 102).

Hattie \& Timperley (2007) har delt opp effektive tilbakemeldinger i tre kategorier; «feed up» (studenter undersøker et tema), «feedback» (tilbakemeldinger) og «feed forward» (læreren tilpasser undervisningen på grunnlag av tilbakemeldingene). Hensikten med de tre kategoriene er å svare på spørsmålene «Hvor skal jeg?», «Hvordan kommer jeg dit?» og «Hvor skal jeg etterpå?».

Funn fra refleksjonsloggene viser at studentene stort sett oppfattet fjernveilederen som tilstedeværende, og at de følte seg sett og hørt selv om de ikke alltid fikk individuell veiledning. Studentenes refleksjoner kan peke på en opplevelse av både «feed up» og «feed forward» som kunne hjelpe dem med å komme videre med ferdighetene de trente på. For noen gjaldt dette uavhengig av hvor fjernveilederen var lokalisert. Veilederens evne til å gi tilbakemelding til gruppen samt å henvende seg til enkeltstudenter i gruppen syntes å være av betydning for studentene. Det vi vet, er at individuelle tilbakemeldinger 
på en oppgave er mer effektive enn tilbakemeldinger rettet mot en gruppe (Hattie \& Timperley, 2007). Funn fra videoopptakene viser bare noen få situasjoner der tilbakemeldinger ble gitt individuelt. Tilbakemeldinger ble for det meste gitt i plenum, og det at andre studenter kunne høre hva som ble sagt til en student, kan ha påvirket kvaliteten på tilbakemeldingene som ble gitt. Det kan tenkes at kritiske tilbakemeldinger, bevisst eller ubevisst, ble holdt tilbake for å beskytte studentens integritet. Med muligheten for mer individuell veiledning kunne mer konkrete og kritiske tilbakemeldinger ha bidratt til større læringsutbytte for studenten.

Videoopptakene viste også noen svakheter ved veiledningen da den telemedisinske enheten ble brukt. Synsområdet sett fra fjernveilederens side var smalt og fokusert og ga ikke et bilde av rommet i vidvinkel. I videoopptakene oppdaget vi at den fokuserte synsvinkelen gjorde at veilederen kunne miste informasjon rundt studenten, noe som gjorde det vanskelig å få med seg alt som skjedde i studentenes ferdighetstrening. Dette kan føre til manglende veiledning i mulige kritiske faser i læringssituasjonen, noe som man bør ta hensyn til når man bruker slik teknologi.

En omfattende studie av sykepleierutdanninger i USA gjorde at Benner et al. (2010) etterlyste en radikal og global omlegging av sykepleierutdanningen. De hevdet at utgangspunktet for denne omleggingen særlig var knyttet til hvordan man underviser sykepleie. Endringer i strukturen og i tilnærmingen til undervisning og læring kan bedre forberede sykepleiere til de fremtidige utfordringene som følger med endret demografi. Benner et al. (2010) observerte at utdanningene i stor grad dro en tydelig grense mellom teori og praksis. Inndelingen av undervisningen var knyttet til enten læring i kliniske miljøer eller klasseromsmiljøer. Slik utdanningene var organisert på tidspunktet da studien ble utført, var det opp til studenten å få «puslespillet sykepleie» til å gå opp (Benner et al., 2010). Vår studie viser at det også her er et nokså distinkt skille mellom teoretisk undervisning og praksis, men den viser at det er mulig med endrete tilnærminger til undervisning og læring, og at man kan prøve ut kreative måter å lære (deler av) et tradisjonsrikt fag. I en videreføring kan også teknologistøttet undervisning knyttes tettere opp mot praksis, slik Benner et al. (2010) etterlyser. For eksempel kan det prøves ut at fjernveilederen eller den lokale veilederen er sykepleiere fra praksisfeltet som kan bringe inn den konkrete relevansen for studentenes fremtidige møter med pasienter. 


\section{Betydning av teknologistøttet ferdighetstrening for fremtidens sykepleie}

I distriktene i Nord-Norge ble det meldt et behov for helsetjenester basert på lokal arbeidskraft for over 20 år siden, men temaet er stadig like aktuelt. For å rekruttere fremtidige sykepleiere i distriktsområder i Nord-Norge ble DSU opprettet for å tilby sykepleierutdanning på fire forskjellige steder utenfor hovedcampus (Norbye \& Skaalvik, 2013). Studenter som er tatt opp ved DSU, får som nevnt sin bachelorutdanning gjennom en kombinasjon av undervisning på distriktsstudiesentre i nærheten av hjemstedet og samlinger ved hovedcampus. Studenter ved DSU er stort sett over 30 år og har familie- og arbeidsforpliktelser på hjemstedet (Norbye \& Skaalvik, 2013). Undervisning og veiledning har som nevnt en «blended learning»-tilnærming (Daniel, 2017; Margaryan et al., 2004), som kombinerer tradisjonelle læringsaktiviteter gjennom forelesninger på studiestedet, nettbaserte læringsmoduler, videokonferanser og praktisk ferdighetstrening av de lokale lærerne på stedet.

Andre nordlige, rurale områder tilbyr lignende sykepleierutdanningsmodeller. University of Saskatchewan i Canada har siden 2012 utviklet et «Lær der du bor»-program for sykepleierstudenter. Programmet innbefatter studenter som lærer i landlige og avsidesliggende områder støttet av den samme teknologien som $\mathrm{i}$ vårt prosjekt, $\mathrm{i}$ tillegg til undervisning ansikt-til-ansikt. Målet med denne organiseringen var å hindre at geografisk beliggenhet ble en ulempe for sykepleierstudenter i distriktene - den geografiske beliggenheten ble snarere plassert i sentrum av læringen, mens læreren ble den som var på et fjerntliggende sted (Butler et al., 2016). Modellen bygde også opp lokal kompetanse da sykepleierne på stedet lærte seg nye pedagogiske tilnærminger, noe som økte deres selvtillit og ferdigheter i undervisningen, slik at de bedre kunne veilede studenter og samarbeide med kolleger i det kliniske miljøet (Butler et al., 2016). Denne tilnærmingen har gjennom UArctic Northern Nursing Education Network også blitt tatt i bruk i North-Eastern Federal University i Yakutsk i Sibir og ved UiT Norges arktiske universitet (Butler et al., 2016).

Tidligere forskning på DSU viser at 20 års kontinuerlig utvikling av sykepleierutdanningen har bidratt til kompetente sykepleiere i tillegg til en bærekraftig helsetjeneste i Nord-Norge (Norbye \& Skaalvik, 2013). Det viser også 
at kvinner i lokalsamfunn i distriktene, med sine forpliktelser, kan bidra til lokalsamfunnet uten at det går på bekostning av forpliktelsene i hjemmet.

Funnene fra dette pilotprosjektet støtter de tidligere funnene til Norbye og Skaalvik (2013). Tilbudet med ferdighetstrening uavhengig av beliggenhet kan bidra til å skape likeverdige muligheter for sykepleierstudenter som bor i distriktene, og sikre fortsatt tilførsel av kompetanse og arbeidskraft lokalt. Det er ikke mulig å dra noen konklusjoner ut fra vårt datamateriale når det gjelder hvordan pilotprosjektet påvirker studentenes gjennomføringsgrad ved DSU, men det kan være at en slik undervisningform kan lette forpliktelsene til studenter både familiært og arbeidsmessig. Flere av studentene uttrykte også opplevelsen av å få nærmere tilknytning til hovedcampus gjennom fjernveilederen og at variasjonen i læringsaktivitetene med bruk av bilder, filmer og liknende opplevdes fremmende for læring. Også variasjonen i form av flere lærere som følger opp, kan ha hatt betydning. Der studentene ellers ville ha reist inn til hovedcampus med de utgiftene og logistiske utfordringene det kunne medføre, kan en slik type undervisning gi et tilsvarende tilbud, i hvert fall innenfor enkelte tema.

\section{Implikasjoner for fremtiden}

Covid-19-pandemien som har rammet verden i 2020, har gjort at mange undervisere $\mathrm{i}$ høyere utdanning har fått oppleve både gleder og frustrasjoner knyttet til bruk av teknologi i undervisning av sykepleierstudenter. Ulike digitale løsninger som Zoom, Microsoft Teams og Skype har blitt en del av den daglige undervisningspraksisen til undervisere, og komfortsonen har blitt betydelig utfordret. Digitale løsninger skaper muligheter for dialog med studenter over lange distanser, og dette muliggjør også noen typer ferdighetstrening.

Til forskjell fra de ovennevte digitale løsningene er det i vårt tilfelle funksjonen til den telemedisinske enheten som har gitt merverdi. Gjennom bruk av medisinsk-teknisk utstyr får studenten utvidete muligheter for læring av praktiske ferdigheter. Samhandlingen mellom sykepleierstudenten og veileder rundt konkrete ferdigheter i sanntid kan bidra til en opplevelse av «hands on»-veiledning på tross av distansen. Det krever imidlertid fysisk tilstedeværelse for studentene der den telemedisinske enheten befinner seg, noe som har vært utfordrende i 2020. 
Studien vår viser uansett at det er mulig å gjennomføre ferdighetstrening på denne måten, og at det av studentene oppleves i stor grad positivt. Allikevel er det fortsatt et skille mellom teori og praksis, som Benner et al. (2010) peker på, i denne undervisningsformen også. I fremtiden kunne det være interessant å knytte tettere bånd til ulike praksisfelt og for eksempel flytte den bærbare enheten ut i praksisstudier eller koble praksisfeltet både i sentrale områder og i distriktet tettere inn i ferdighetstreningen. Det kunne også være interessant å følge studentene i deres kliniske praksis for å utforske om og hvordan de bruker kunnskapen og ferdighetene som de har trent på, i temaøktene med det telemedisinske utstyret. Dette i tråd med tanken om at bruk av teknologi i utdanningen kan gi trygghet i bruk av teknologi som en del av pasientarbeid. En del av disse studentene vil arbeide i rurale helsetjenester og vil benytte medisinsk-teknisk utstyr for å knytte fagkompetanse nærmere seg uten å flytte pasientene.

Videre hadde det vært interessant å utforske hvordan samarbeid og praksisfellesskap mellom veiledere kunne fortonet seg dersom denne måten å drive ferdighetstrening på ble videreført.

Vi har tro på at en slik læringsaktivitet, gjennom bevisst organisering, tydeligere oppmerksomhet på tilbakemeldinger og tettere tilknytning til praksisfeltet, kan gi variasjon, fleksibilitet og kvalitet for sykepleierstudenter som gjennomfører sin utdanning i distriktet.

\section{Takk}

Vi vil gjerne rette en takk til alle som bidro til at vi fikk prøvd ut denne teknologien $\mathrm{i}$ et samarbeid: takk til University of Saskatchewan for lånet av utstyret og støtte i å installere og klargjøre software/programvaren. Takk til Nordreisa videregående skole som la til rette for bruk av ny teknologi i deres lokaler. Takk også til Det helsevitenskapelige fakultet som ga oss mulighet til å kjøpe inn et elektronisk stetoskop som kunne kobles til enheten. Og sist, men ikke minst, takk til studentene som villig stilte opp og ga oss verdifulle data til bruk i forskningen, og til ny kunnskap vi har med oss videre i arbeid med bruk av teknologi over distanse. 


\section{Referanser}

Baxter, P. \& Jack, S. (2008). Qualitative case study methodology: Study design and implementation for novice researchers. The qualitative report, 13(4), s. 544-559. DOI: https://doi.org/10.46743/2160-3715/2008.1573

Benner, P. (1984). From novice to expert: excellence and power in clinical nursing practice. Menlo Park, Calif: Addison-Wesley.

Benner, P., Sutphen, M., Leonard, V. \& Day, L. (2010). Educating nurses: a call for radical transformation (Preparation for the professions series, bd. 3). San Francisco, Calif: Jossey-Bass.

Bezemer, J. \& Mavers, D. (2011). Multimodal transcription as academic practice: A social semiotic perspective. International Journal of Social Research Methodology, 14(3), s. 191-206. DOI: https://doi.org/10.1080/13645579.2011.563616

Bjørk, I. T. (1999). Practical skill development in new nurses. Nursing Inquiry, 6(1), s. 34-47. DOI: https://doi.org/10.1046/j.1440-1800.1999.00005.x

Bjørk, I. T. (2003). Refleksjon over egen praksis. I I. T. Bjørk \& M. S. Bjerknes (Red.), A lare i praksis: en veiviser for studenten. Oslo: Universitetsforlaget.

Bjørk, I. T. \& Bjerknes, M. S. (2003). Å lare i praksis: en veiviser for studenten. Oslo: Universitetsforlaget.

Bjørndal, C. R. P. (2011). Hva slags kompetanse trenger veilederen? Tre alternative forståelser. I T. J. Karlsen (Red.), Veiledning under nye vilkår: skapende prosesser $i$ motet mellom veileder og veisøker. Oslo: Gyldendal akademisk.

Boud, D., Cohen, R. \& Sampson, J. (2014). Peer learning in higher education: Learning from and with each other: Routledge.

Braun, V. \& Clarke, V. (2006). Using thematic analysis in psychology. Qualitative Research in Psychology, 3(2), 77. 101.

DOI: https://doi.org/10.1191/1478088706qp063oa

Braun, V. \& Clarke, V. (2013). Successful qualitative research : a practical guide for beginners. Los Angeles, Calif: Sage.

Braun, V. \& Clarke, V. (2020). One size fits all? What counts as quality practice in (reflexive) thematic analysis? Qualitative Research in Psychology, s. 125. DOI: https://doi.org/10.1080/14780887.2020.1769238

Butler, L., Bullin, C., Bally, J., Tomtene, M. \& Neuls, E. (2016). Learn where you live, teach from a distance: Choosing the best technology for distributed nursing education. Northern Review, (43). https://thenorthernreview.ca/index.php/nr/ article/view/590/yukoncollege.yk.ca/yukoncollege.yk.ca/review 
Creswell, J. W. \& Poth, C. N. (2018). Qualitative inquiry \& research design: choosing among five approaches ( $4^{\text {th }}$ ed. Qualitative inquiry and research design). Los Angeles: SAGE Publications.

Daniel, S. J. (2017). Making sense of Blended Learning: Treasuring an older tradition or finding a better future? Foredrag holdt ved World Conference on Online Learning. Teaching in the Digitale Age. Toronto, Canada.

Dean, S., Williams, C. \& Balnaves, M. (2015). Practising on plastic people: Can I really care? Contemporary nurse, 51(2-3), s. 257-271.

DOI: https://doi.org/10.1080/10376178.2016.1163231

Elden, M. \& Levin, M. (1991). Cogenerative Learning. Bringing Participation Interaction Research. In W. F. Whyte (Ed.). Participatory Action Research, s. 127-142. Newbury Park, CA: Sage Publications.

DOI: https://doi.org/10.4135/9781412985383.n9

Garcez, A., Duarte, R. \& Eisenberg, Z. (2011). Production and analysis of video recordings in qualitative research. Educação e Pesquisa, 37(2), s. 249-261. DOI: https://doi.org/10.1590/S1517-97022011000200003

Hattie, J. \& Timperley, H. (2007). The Power of Feedback. Review of Educational Research, 77(1), 81-112. DOI: https://doi.org/10.3102/003465430298487

Holt, T., Hansen, G., McKinney, V. \& Mendez, I. (2018). Contemplating remote presence technology for culturally safe health care for rural indigenous children. AlterNative: An International Journal of Indigenous Peoples, 15(1), s. 31-33. DOI: https://doi.org/10.1177/1177180118806430

Holt, T., Sari, N., Hansen, G., Bradshaw, M., Prodanuk, M., McKinney, V., Mendez, I. (2018). Remote Presence Robotic Technology Reduces Need for Pediatric Interfacility Transportation from an Isolated Northern Community. Telemed J E Health, 24(11), s. 927-933.

DOI: https://doi.org/10.1089/tmj.2017.0211

Lauvås, P. \& Handal, G. (2014). Veiledning og praktisk yrkesteori (3. utg.). Oslo: Cappelen Damm akademisk.

Lave, J. \& Wenger, E. (2003). Situeret lering - og andre tekster (Situated learning legitimate peripheral participation). København: Reitzel.

Margaryan, A., Collis, B. \& Cooke, A. (2004). Activity-based blended learning. Human resource development international, 7(2), s. 265-274.

DOI: https://doi.org/10.1080/13678860410001676574

Munshi, F., Lababidi, H. \& Alyousef, S. (2015). Low-versus high-fidelity simulations in teaching and assessing clinical skills. Journal of Taibah University Medical Sciences, 10(1), s. 12-15. DOI: https://doi.org/10.1016/j.jtumed.2015.01.008 
Norbye, B. \& Skaalvik, M. W. (2013). Decentralized nursing education in Northern Norway: towards a sustainable recruitment and retention model in rural Arctic healthcare services. International journal of circumpolar health, 72(1), 22793. DOI: https://doi.org/10.3402/ijch.v73.25328

Skaalvik, M. W. \& Norbye, B. (2016). A Decentralized Nursing Education. Northern Review, (43). https://thenorthernreview.ca/index.php/nr/article/ view/588. Data accessed 02.11.2021.

Sommer, I., Larsen, K., Nielsen, C., Frederiksen, A.-M. S., Bjørk, I. T., Lomborg, K., Reierson, I. Å. (2011). Modell for praktisk ferdighetsutøvelse som læringsog veiledningsredskap. Hentet 03.11.21 fra http://www.rins.dk/educationalmaterial.html

Tveiten, S. (2013). Veiledning: mer enn ord (4. utg. utg.). Bergen: Fagbokforlaget.

VAR Healthcare. (2018). Auskultatorisk måling av blodtrykk på overarm.

I VAR Healthcare. Hentet 23.01.2020 https://www.varnett.no/portal/ procedure/7598/14

Yuan, H., Williams, B. \& Fang, J. (2012). The contribution of high-fidelity simulation to nursing students' confidence and competence: a systematic review. International Nursing Review, 59(1), s. 26-33.

DOI: https://doi.org/10.1111/j.1466-7657.2011.00964.x 